\title{
KINETIC PROPERTIES OF ADENOSINE TRIPHOSPHATE SULFURYLASE OF INTESTINAL SULFATE-REDUCING BACTERIA
}

\author{
I. V. KUSHKEVYCH ${ }^{1,2}$, H. L. ANTONYAK ${ }^{3}$, M. BARTOŠ ${ }^{2}$ \\ ${ }^{1}$ Institute of Animal Biology, NAAS of Ukraine, Lviv; \\ ${ }^{2}$ University of Veterinary and Pharmaceutical Sciences of Brno, Czech Republic; \\ ${ }^{3}$ Ivan Franko National University of Lviv, Ukraine; \\ e-mail: ivan.kushkevych@gmail.com
}

The investigation of specific activity of ATP sulfurylase and kinetic properties of the enzyme in cellfree extracts of intestinal bacterial strains Desulfovibrio piger Vib-7 and Desulfomicrobium sp. Rod-9 is presented. The microbiological, biochemical, biophysical and statistical methods were used in the work. The optimal temperature $\left(35^{\circ} \mathrm{C}\right)$ and $\mathrm{pH}$ 8.0-8.5 for enzyme reaction were determined. An analysis of kinetic properties of ATP sulfurylase has been carried out. Initial (instantaneous) reaction velocity $\left(V_{0}\right)$, maximum amount of the product of reaction $\left(P_{\max }\right)$, the reaction time (half saturation period, $\left.\tau\right)$ and maximum velocity of the ATP sulfurylase reaction $\left(V_{\text {max }}\right)$ have been defined. Michaelis constants $\left(K_{m}^{\text {Sulfate }}, K_{m}{ }^{A T P}, K_{m}{ }^{A P S}\right.$, and $K_{m}^{\text {Pyrophosphate }}$ of the enzyme reaction were demonstrated for both D. piger Vib-7 and Desulfomicrobium sp. Rod-9 intestinal bacterial strains.

Ke y word s: kinetic analysis, sulfate-reducing bacteria, Desulfovibrio piger, Desulfomicrobium sp., ATP sulfurylase, intestinal microbiocenosis, inflammatory bowel diseases, ulcerative colitis.

$\mathrm{U}$ lcerative colitis is one of the most common acute inflammatory bowel diseases. The development of this disease depends on human nutrition and the qualitative and quantitative composition of intestinal microbiocenosis [3, 12]. The active agents of ulcerative colitis and inflammatory bowel diseases can be sulfate-reducing bacteria which occur in the gut flora of about $50 \%$ of healthy persons [7].

The process of the dissimilatory sulfate reduction to sulfide is provided due to the enzyme activity of the bacteria [2]. Sulfate is a stable nonreactive compound that must be activated to participate in subsequent metabolic reactions, such as sulfate reduction and sulfur transfer [11]. The first activation step in assimilation and dissimilation pathways of sulfate reduction is accomplished by transferring and coupling the adenosine 5 '-phosphoryl moiety of ATP to sulfate $[2,16]$. This reaction catalyzed by ATP sulfurylase (ATP sulfate adenyltransferase, EC 2.7.7.4) is represented by the equation: ATP + $+\mathrm{SO}_{4}{ }^{2-} \leftrightarrow$ APS $+\mathrm{PP}_{\mathrm{i}}$. The enzyme plays a crucial role in sulfate activation, the key step for sulfate utilization. It was found in Desulfovibrio desulfuricans ATCC 27774 and Desulfovibrio gigas [6].
The dissimilation process occurring in these organisms involves adenosine phosphosulfate (APS) as the active intermediate compound $[11,16]$. In sulfate-reducing bacteria of the genus Desulfovibrio the APS is reduced to AMP and sulfite through the mediation of APS reductase [2, 6]. Sulfite is further reduced to hydrogen sulfide, the final product of the sequential reactions. Hydrogen sulfide accumulated in the human intestine is cytotoxic and carcinogenic to its cells causing inhibition of cytochrome oxidase, oxidation processes of butyrate by colonocytes, and destruction of epithelial cells, ulcers, inflammation with subsequent development of colon cancer $[3,7,12]$.

As far as it is aware, ATP sulfurylase from intestinal sulfate-reducing bacteria $D$. piger and Desulfomicrobium has never been well-characterized. In literature, there are a lot of data about ATP sulfurylase of the sulfate-reducing bacteria isolated from the environment $[2,6,10,16]$. However, the data about activity of this enzyme from intestinal sulfate-reducing bacteria Desulfovibrio piger and Desulfomicrobium sp. has not been yet reported.

The aim of our work was to study specific activity of ATP sulfurylase in cell-free extract of in- 
testinal sulfate-reducing bacteria $D$. piger Vib-7 and Desulfomicrobium sp. Rod-9 and to carry out the kinetic analysis of enzymatic reaction.

\section{Materials and Methods}

Objects of the study were sulfate-reducing bacteria Desulfovibrio piger Vib-7 and Desulfomicrobium sp. Rod-9 isolated from the human large intestine and identified $[13,14]$.

Bacterial growth and cultivation. Bacteria were grown in a nutrition-modified Kravtsov-Sorokin's liquid medium [13]. Before seeding bacteria in the medium, $0.05 \mathrm{ml} / 1$ of sterile solution of $\mathrm{Na}_{2} \mathrm{~S} \times 9 \mathrm{H}_{2} \mathrm{O}$ $(1 \%)$ was added. A sterile $10 \mathrm{~N}$ solution of $\mathrm{NaOH}$ $(0.9 \mathrm{ml} / \mathrm{l})$ in the medium was used to provide the final $\mathrm{pH}$ 7.2. The medium was heated in boiling water for $30 \mathrm{~min}$ in order to obtain the oxygen-free medium, and then cooled to $30^{\circ} \mathrm{C}$. The bacteria were grown for $72 \mathrm{~h}$ at $37^{\circ} \mathrm{C}$ under anaerobic conditions. The tubes were brim-filled with the medium and closed to provide anaerobic conditions.

Obtaining of cell-free extracts. Cells were harvested at the beginning of the stationary phase, suspended in $10 \mathrm{mM}$ Tris- $\mathrm{HCl}$ buffer in a 1/1 ratio (w/v) at $\mathrm{pH}$ 7.6, and disrupted using a Manton-Gaulin press at 9000 psi. The extract was centrifuged at $15,000 \mathrm{~g}$ for $1 \mathrm{~h}$; the pellet was then used as sedimentary fraction, and the supernatant obtained was the termed soluble fraction [6]. This extract was subjected to further centrifugation at $180,000 \mathrm{~g}$ for $1 \mathrm{~h}$ to eliminate the membrane fraction. A pure supernatant, containing the soluble fraction, was then used as cell-free extract. Protein concentration in the cell-free extracts was determined by the Lowry method [15].

Assays for ATP sulfurylase activity. The enzyme was assayed as described in paper [18]. Initial reaction velocities were determined by observing the rate of change in absorbance of pyridine nucleotide at $340 \mathrm{~nm}$ in $500 \mu \mathrm{l}$ systems at $25^{\circ} \mathrm{C}$ using a Beckman spectrophotometer. For providing the forward APS synthesis reaction the assay system was used which consisted of $50 \mathrm{mM}$ Tris ( $\mathrm{pH} 8.0), 15 \mathrm{mM}$ $\mathrm{MgCl}_{2}, 100 \mathrm{mM} \mathrm{NaCl}, 0.4 \mathrm{mM}$ phosphoenolpyruvate, $0.2 \mathrm{mM}$ NADH, 0.05 units of APS kinase, 20 units of pyruvate kinase and 30 units of lactate dehydrogenase. The specific activity of APS kinase $\left(1.5 \mu \mathrm{mol} \times \mathrm{min}^{-1} \times \mathrm{mg}^{-1}\right)$ was determined spectrophotometrically, as described in [17]. For the reverse ATP synthesis reaction we used an assay system of $50 \mathrm{mM}$ Tris (pH 8.0), $5 \mathrm{mM} \mathrm{MgCl}, 1 \mathrm{mM} \mathrm{NADP}{ }^{+}$,
$1 \mathrm{mM}$ glucose, 2 units of hexokinase and 1 unit of glucose-6-phosphate dehydrogenase [4]. All reactions were initiated by addition of enzyme and were corrected for non-enzymatic rates. One unit of enzyme activity is defined as the amount of enzyme that produces $1 \mu \mathrm{mol}$ of primary product per minute. Specific enzyme activity was expressed as $U \times \mathrm{mg}^{-1}$ protein. The activity of the studied enzyme in the cell-free extracts of both bacterial strains under the effect of different temperature (from 20 to $45{ }^{\circ} \mathrm{C}$ ) and $\mathrm{pH}$ (in the range from 4.0 to 10.0 ) in the incubation medium was measured.

Kinetic analysis. Kinetic analysis of the enzyme reaction was performed in the standard incubation medium (as it was described above) with modified physical and chemical characteristics of the respective parameters (the incubation time, substrate concentration, temperature and $\mathrm{pH}$ ). The determined kinetic parameters characterizing the ATP sulfurylase reaction are as follows: the initial (instantaneous) reaction velocity $\left(V_{0}\right)$, maximum velocity of the reaction $\left(V_{\max }\right)$, maximum amount of the reaction product $\left(\mathrm{P}_{\max }\right)$ and characteristic reaction time (time of half saturation) [9]. The amount of the reaction product was calculated stoichiometrically. The kinetic parameters characterizing ATP sulfurylase reactions such as Michaelis constant $\left(K_{\mathrm{m}}\right)$ and maximum reaction velocity of substrate decomposition were determined by Lineweaver-Burk plot [8]. To analyze the substrate kinetic mechanism of ATP sulfurylase, initial velocities were measured under standard assay conditions with different substrate concentrations. In the forward direction, assays used varied $\mathrm{Na}_{2} \mathrm{SO}_{4}$ and ATP concentrations. For the reverse reaction, initial velocities were determined using varied APS and sodium $\mathrm{PP}_{\mathrm{i}}$ concentrations. The resulting data were also analyzed by global curve fitting in SigmaPlot (Systat Software, Inc.) to model the kinetic data for rapid equilibrium rate equations describing ordered sequential, $V=\left(V_{\max }[\mathrm{A}][\mathrm{B}]\right) /\left(K_{\mathrm{A}} K_{\mathrm{B}}+K_{\mathrm{B}}[\mathrm{A}]+\right.$ $+[\mathrm{A}][\mathrm{B}])$, and random sequential, $V=\left(V_{\max }[\mathrm{A}][\mathrm{B}]\right) /$ $\left(\alpha K_{\mathrm{A}} K_{\mathrm{B}}+K_{\mathrm{B}}[\mathrm{A}]+K_{\mathrm{A}}[\mathrm{B}]+[\mathrm{A}][\mathrm{B}]\right)$, kinetic mechanisms, where $V$ is the initial velocity, $V_{\text {max }}$ is the maximum velocity, $K_{\mathrm{A}}$ and $K_{\mathrm{B}}$ are the $K_{\mathrm{m}}$ values for substrates $A$ and $B$, respectively, and $\alpha$ is the interaction factor if the binding of one substrate changes the dissociation constant for the other [19].

Statistical analysis. Kinetic and statistical calculations of the results were carried out using the software MS Office and Origin computer programs. The research results were processed by 
the methods of variation statistics using Student $t$-test. The equation of the straight line that the best approximates the experimental data was calculated by the method of least squares. The absolute value of the correlation coefficient $r$ was from 0.90 to 0.98 . The significance of the calculated parameters of the line was tested by the Fisher's F-test. The accurate approximation was observed when $P \leq 0.05$ [1].

\section{Results and Discussion}

Specific activity of ATP sulfurylase, an important enzyme in the process of sulfate transport in sulfate-reducing bacteria, in different fractions of D. piger Vib-7 and Desulfomicrobium sp. Rod-9 was determined (Table 1). Results of our study showed that the specific activity of the enzyme in cell-free extracts $\left(2.26 \pm 0.231\right.$ and $0.98 \pm 0.0082{\mathrm{U} \times \mathrm{mg}^{-1} \text { pro- }}^{-}$ tein for $D$. piger Vib-7 and Desulfomicrobium sp. Rod-9, respectively) was measured. Slightly higher values of activity of ATP sulfurylase was determined in the soluble fraction compared to cell-free extracts.

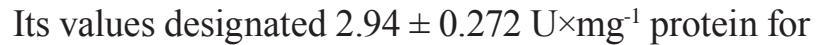
D. piger Vib-7 and $1.12 \pm 0.121{\mathrm{U} \times \mathrm{mg}^{-1}}^{-1}$ protein for Desulfomicrobium sp. Rod-9. The enzyme activity was not observed in sedimentary fraction.

The effect of temperature and $\mathrm{pH}$ of the reaction mixture on ATP sulfurylase activity in the cellfree extracts of the sulfate-reducing bacteria was studied (Fig. 1). The maximum specific activity for both bacterial strains was determined at $35^{\circ} \mathrm{C}$. An increase or decrease in temperature led to a decrease of the activity of studied enzyme in the cell-free bacterial extracts. The highest enzyme activity of ATP sulfurylase was determined in the cell-free extracts of the D. piger Vib-7 and the Desulfomicrobium sp. Rod-9 at $\mathrm{pH}$ 8.0-8.5.

Thus, temperature and $\mathrm{pH}$ optimum of this enzyme was $35^{\circ} \mathrm{C}$ and $\mathrm{pH} 8.0-8.5$, respectively. The enzyme activity exhibited typical bell-shaped curves as a function of temperature and $\mathrm{pH}$.

To study the characteristics and mechanism of ATP sulfurylase reaction, the initial (instantaneous) reaction velocity $\left(V_{0}\right)$, maximum velocity of the reaction $\left(V_{\max }\right)$, maximum amount of reaction product $\left(\mathrm{P}_{\max }\right)$ and reaction time $(\tau)$ were determined. Dynamics of APS accumulation in the cell-free extracts of D. piger Vib-7 and Desulfomicrobium sp. Rod-9 was studied for investigation of the kinetic parameters of ATP sulfurylase (Fig. 2).

Experimental data showed that the kinetic curves of ATP sulfurylase activity have a tendency to saturation (Fig. 2, A). The analysis of the results allows one to make the conclusion that the kinetics of ATP sulfurylase activity in cell-free extracts of the sulfate-reducing bacteria was consistent to the zeroorder reaction in the range of $0-10 \mathrm{~min}$ (the graph of the dependence of product formation on the incubation time was almost linear in this interval of time). Therefore the duration of the incubation of bacterial cells extracts was 10 min in subsequent experiments.

The amount of ATP sulfurylase reaction product in the $D$. piger Vib-7 was higher $(97.13 \pm 8.91$ $\mu$ mol $\times \mathrm{mg}^{-1}$ protein) compared to the Desulfomicrobium sp. Rod-9 $\left(36.24 \pm 3.43 \mu \mathrm{mol} \times \mathrm{mg}^{-1}\right.$ protein $)$ in the entire range of time factor. The basic kinetic properties of the reaction in the cell-free extracts of the sulfate-reducing bacteria were calculated by linearization of the data in the $\{\mathrm{P} / \mathrm{t} ; \mathrm{P}\}$ coordinates (Fig. 2, B, Table 2).

The kinetic parameters of ATP sulfurylase in cell-free extracts of both D. piger Vib-7 and Desulfomicrobium sp. Rod-9 were significantly different. The values of initial (instantaneous) reaction velocity $\left(V_{0}\right)$ for ATP sulfurylase activity was calculated by the maximal amount of the product reaction $\left(\mathrm{P}_{\max }\right)$. As shown in Table 2, $V_{0}$ for ATP sulfurylase reac-

Ta b le 1. ATP sulfurylase activity in different fractions obtained from cells of Desulfovibrio piger Vib-7 and Desulfomicrobium sp. Rod-9

\begin{tabular}{l|c|c|c}
\hline \multirow{2}{*}{ Sulfate-reducing bacteria } & \multicolumn{2}{|c}{ Specific activity of ATP sulfurylase $\left(\mathrm{U} \times \mathrm{mg}^{-1}\right.$ protein) } \\
\cline { 2 - 4 } & \multirow{2}{*}{ Cell-free extract } & \multicolumn{2}{|c}{ Individual fractions } \\
\cline { 3 - 4 } & & Soluble & Sedimentary \\
\hline Desulfovibrio piger Vib-7 & $2.26 \pm 0.231$ & $2.94 \pm 0.272$ & 0 \\
Desulfomicrobium sp. Rod-9 & $0.98 \pm 0.0082^{* *}$ & $1.12 \pm 0.121^{* * *}$ & 0 \\
\hline
\end{tabular}

Comment: The assays were carried out at a protein concentration of $44.93 \mathrm{mg} / \mathrm{ml}$ (for D. piger Vib-7) and $38.14 \mathrm{mg} / \mathrm{ml}$ (for Desulfomicrobium sp. Rod-9). Enzyme activity has been determined after 20 min incubation. Significance of the values $M \pm m, n=3$; ** $P<0.01, * * * P<0.001$, compared to $D$. piger Vib-7 strain. 

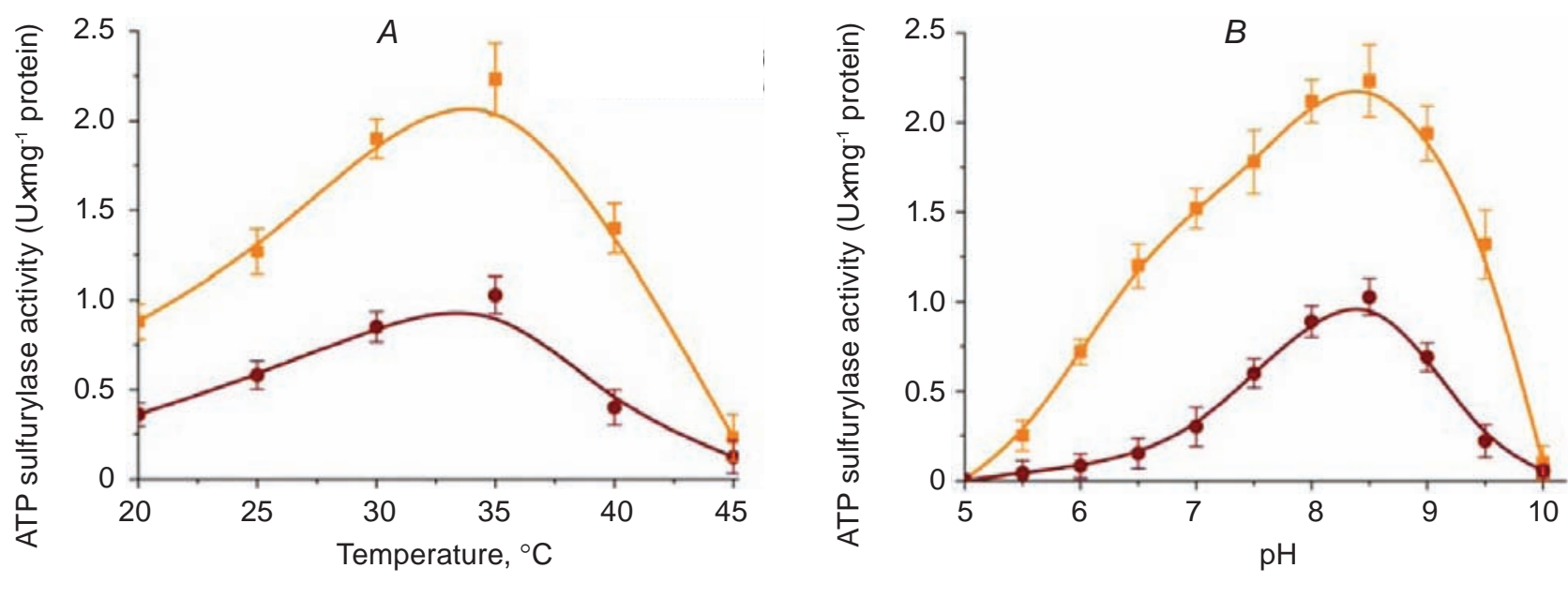

-11-Desulfovibrio pider Vib-7

Desulfomicrobium sp. Rod-9

Fig. 1. The effect of temperature (A) and $p H(B)$ on the dissimilatory ATP sulfurylase activity in the cell-free extracts of D. piger Vib-7 and Desulfomicrobium sp. Rod-9

Table 2. Kinetic parameters of the ATP sulfurylase in the cell-free extracts of Desulfovibrio piger Vib-7 and Desulfomicrobium sp. Rod-9

\begin{tabular}{l|c|c}
\hline \multirow{2}{*}{ Kinetic parameters } & \multicolumn{2}{|c}{ Sulfate-reducing bacteria } \\
\cline { 2 - 3 } & Desulfovibrio piger Vib-7 & Desulfomicrobium sp. Rod-9 \\
\hline$V_{0}\left(\mu\right.$ mol $\times \mathrm{min}^{-1} \times \mathrm{mg}^{-1}$ protein $)$ & $5.48 \pm 0.57$ & $4.12 \pm 0.38$ \\
$\mathrm{P}_{\max }\left(\mu\right.$ mol $\times \mathrm{mg}_{\text {protein })}$ & $97.13 \pm 8.91$ & $36.24 \pm 3.43^{* * *}$ \\
$\tau$ (min) & $17.73 \pm 1.62$ & $8.80 \pm 0.76^{* *}$ \\
\hline
\end{tabular}

Comment: $V_{0}$ is initial (instantaneous) reaction velocity; $\mathrm{P}_{\max }$ is maximum amount (plateau) of the product of reaction; is the reaction time (half saturation period). Significance of the values $M \pm m, n=5 ;{ }^{* *} P<0.01$, ${ }^{* * *} P<0.001$, compared to the $D$. piger Vib-7 strain.

tion was slightly higher in the cell-free extracts of D. piger Vib-7 $\left(5.48 \pm 0.57 \mu \mathrm{mol} \times \mathrm{min}^{-1} \times \mathrm{mg}^{-1}\right.$ protein) compared to Desulfomicrobium sp. Rod-9 $\left(4.12 \pm 0.38 \mu \mathrm{mol} \times \mathrm{min}^{-1} \times \mathrm{mg}^{-1}\right.$ protein $)$. In this case, the value of the reaction time $(\tau)$ was also significantly higher for $D$. piger Vib-7 than for Desulfomicrobium sp. Rod-9 strain. Based on these data, there is an assumption that D. piger Vib-7 can consume sulfate ion much faster in their cells than Desulfomicrobium sp. Rod-9. Moreover, this hypothetical assumption can be also confirmed by the data obtained with maximal velocities of accumulation of the final reaction products, where $V_{\max }$ for $\mathrm{SO}_{4}^{2-}$, ATP, APS, and PPi in the cell-free extracts of D. piger Vib-7 were also more intensively increased compared to Desulfomicrobium sp. Rod-9 (Table 3).
The kinetic analysis of ATP sulfurylase activity dependence on concentration of substrates $\left(\mathrm{SO}_{4}{ }^{2-}\right.$ and ATP) was performed. According to the obtained results, the increase of substráte concentrations from 0.5 to $5.0 \mathrm{mM}$ (for sulfate) and from 0.25 to $3.5 \mathrm{mM}$ (for ATP) causes a monotonic rise of the studied enzyme activity and the activity was maintained on unchanged level (plateau) under substrate concentrations over 5.0 and $3.5 \mathrm{mM}$, respectively (Fig. 2, $C, E)$. Curves of the dependence $\{1 / V ; 1 /[S]\}$ were distinguished by the tangent slope and intersect the vertical axis in one point (Fig. 2, D, F). Additionally, the activity of ATP sulfurylase in cell-free extracts of D. piger Vib-7 and Desulfomicrobium sp. Rod-9 under the effect of different concentrations of APS and pyrophosphate was studied by the reverse reac- 

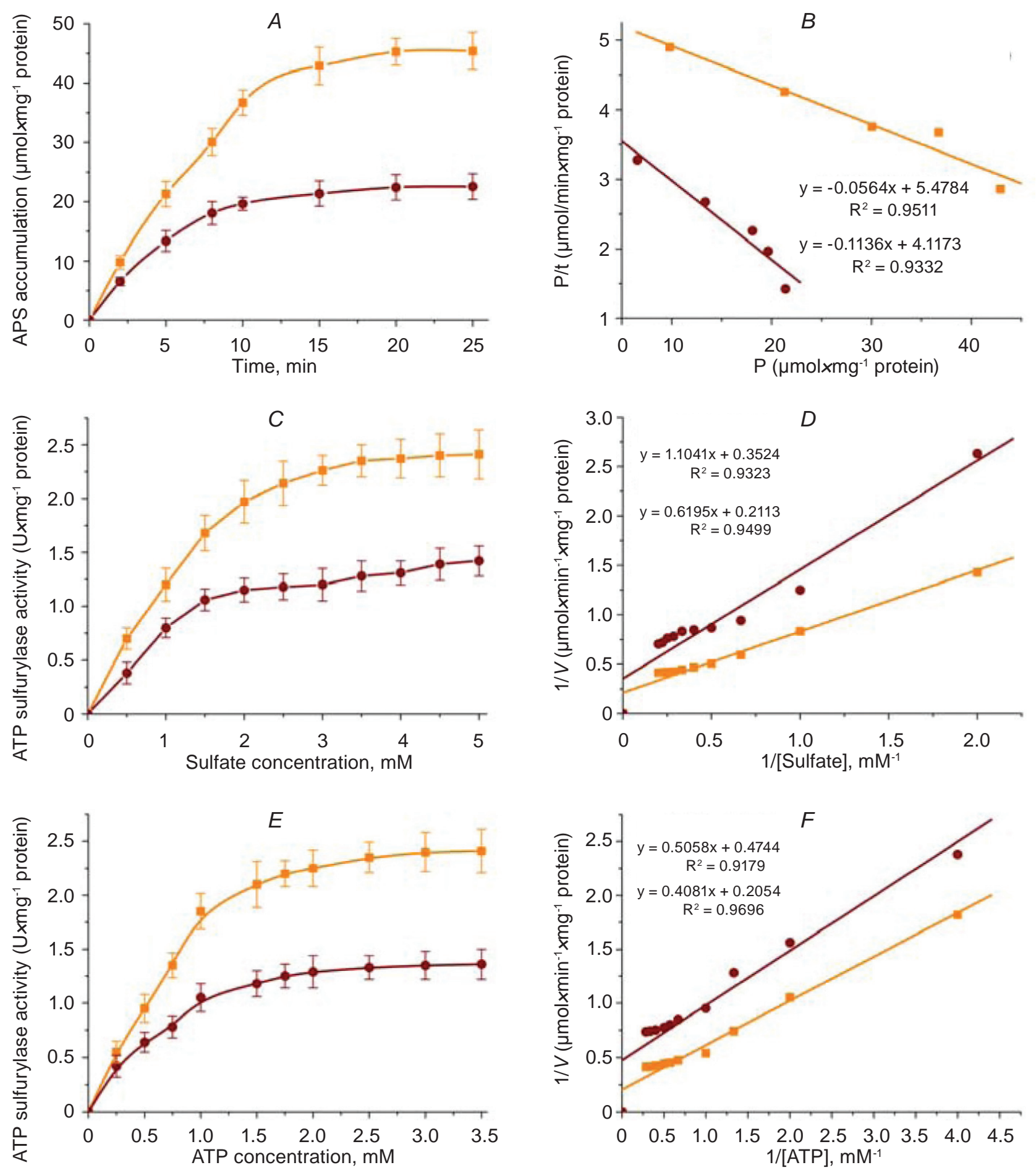

-1E-Desulfovibrio pider Vib-7

Desulfomicrobium sp. Rod-9

Fig. 2. Kinetic parameters of ATP sulfurylase activity in cell-free extracts of D. piger Vib-7 and Desulfomicrobium sp. Rod-9: $A$ - dynamics of product accumulation ( $M \pm m, n=3)$; $B$ - linearization of curves of product accumulation in $\{P / t ; P\}$ coordinates $\left(n=3 ; R^{2}>0.95 ; F<0.02\right) ; C, E$ - the effect of different concentrations of substrate on ATP sulfurylase activity $(M \pm m, n=5) ; D, F$ - linearization of concentration curves, which are shown in fig. 3C, E, in the Lineweaver-Burk plot, where Vis velocity of ATP sulfurylase reaction and [Sulfate] or $[A T P]$ is substrate concentration $\left(n=5 ; R^{2}>0.95 ; F<0.005\right)$ 

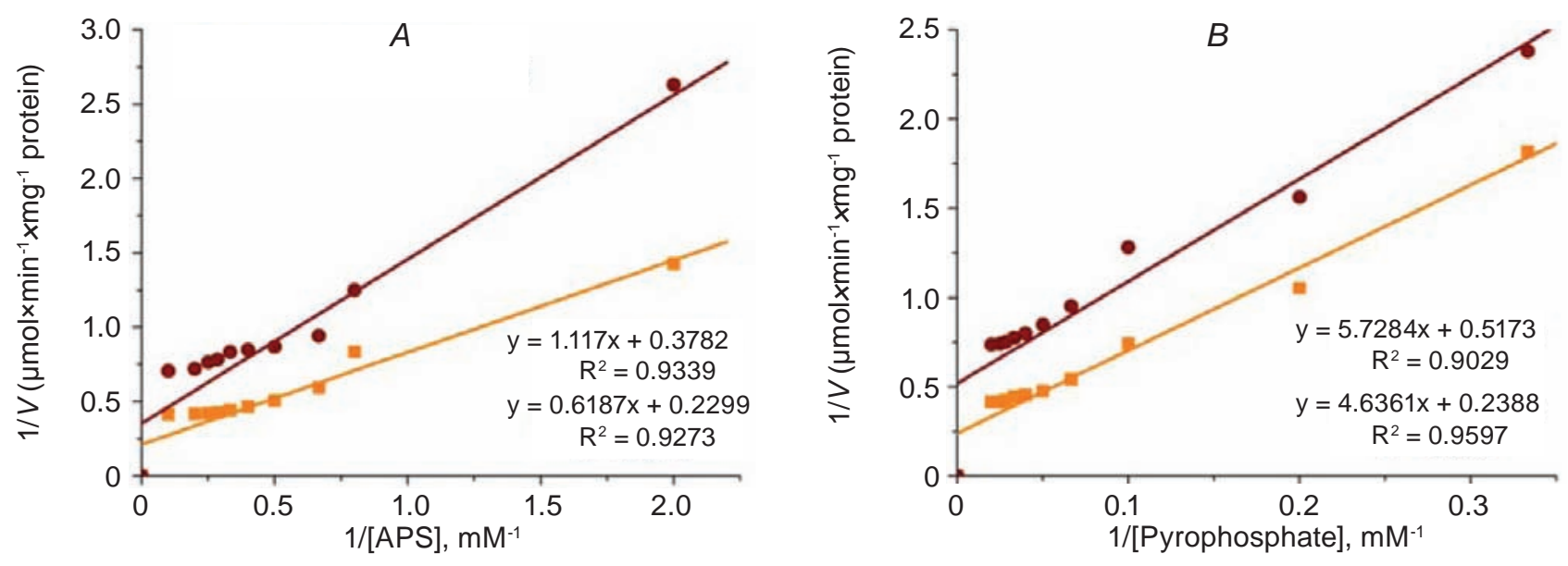

- Desulfovibrio pider Vib-7

Desulfomicrobium sp. Rod-9

Fig. 3. Linearization of the effect of different concentrations of APS (A) and pyrophosphate (B) on ATP sulfurylase activity in cell-free extracts of D. piger Vib-7 and Desulfomicrobium sp. Rod-9, in Lineweaver-Burk plot, where $V$ is velocity of ATP sulfurylase reaction and [APS] or [pyrophosphate] is substrate concentration $\left(n=3 ; R^{2}>0.9 ; F<0.005\right)$

tion (figures not shown). There was similar tendency as described for sulfate and ATP substrates. The linearization of the effect of different concentrations of APS and pyrophosphate on ATP sulfurylase activity was presented in Fig. 3.

The basic kinetic parameters of ATP sulfurylase activity in D. piger Vib-7 and Desulfomicrobium sp. Rod-9 cell-free extracts were identified by linearization of the data in the Lineweaver-Burk plot (Table 3).

Calculation of the kinetic parameters of ATP sulfurylase activity indicates that the maximum velocities $\left(V_{\max }\right)$ of $\mathrm{SO}_{4}{ }^{2-}$, ATP, APS, and $\mathrm{PP}_{\mathrm{i}}$ in the cell-free extracts of $D$. piger Vib-7 and Desulfomicrobium sp. Rod-9 were significantly different from each other. However, it was observed a correlative

Ta b le 3. Kinetic parameters of ATP sulfurylase activity

\begin{tabular}{|c|c|c|}
\hline \multirow{2}{*}{ Kinetic parameters } & \multicolumn{2}{|c|}{ Sulfate-reducing bacteria } \\
\hline & Desulfovibrio piger Vib-7 & Desulfomicrobium sp. Rod-9 \\
\hline \multicolumn{3}{|l|}{ Forward reaction } \\
\hline$V_{\max }$ for $\mathrm{SO}_{4}^{2-}\left(\mu \mathrm{mol} \times \mathrm{min}^{-1} \times \mathrm{mg}^{-1}\right.$ protein $)$ & $4.73 \pm 0.44$ & $2.84 \pm 0.29 *$ \\
\hline$K_{\mathrm{m}}^{\text {Sulfate }}(\mathrm{mM})$ & $2.93 \pm 0.26$ & $3.13 \pm 0.27$ \\
\hline$V_{\max }$ for $\operatorname{ATP}\left(\mu \mathrm{mol} \times \min ^{-1} \times \mathrm{mg}^{-1}\right.$ protein $)$ & $4.87 \pm 0.55$ & $2.11 \pm 0.22^{* *}$ \\
\hline$K_{\mathrm{m}}^{\mathrm{ATP}}(\mathrm{mM})$ & $1.98 \pm 0.21$ & $1.07 \pm 0.12 *$ \\
\hline \multicolumn{3}{|l|}{ Reverse reaction } \\
\hline$V_{\max }$ for APS $\left(\mu \mathrm{mol} \times \min ^{-1} \times \mathrm{mg}^{-1}\right.$ protein $)$ & $4.34 \pm 0.42$ & $2.64 \pm 0.25^{*}$ \\
\hline$K_{\mathrm{m}}^{\mathrm{APS}}(\mathrm{mM})$ & $2.69 \pm 0.23$ & $2.95 \pm 0.31$ \\
\hline$V_{\max }$ for $\mathrm{PP}_{\mathrm{i}}\left(\mu \mathrm{mol} \times \mathrm{min}^{-1} \times \mathrm{mg}^{-1}\right.$ protein $)$ & $4.19 \pm 0.39$ & $1.93 \pm 0.18^{* *}$ \\
\hline$K_{\mathrm{m}}^{\text {Pyrophosphate }}(\mathrm{mM})$ & $19.41 \pm 1.85$ & $11.07 \pm 1.11^{*}$ \\
\hline
\end{tabular}

Comment: $V_{\max }$ is maximum velocity of the enzyme reaction; $K_{\mathrm{m}}$ is Michaelis constant which was determined by substrate. Significance of the values $M \pm m, n=5 ; * P<0.05, * * P<0.01$, compared to the $D$. piger Vib-7 strain. 
relationship between $\mathrm{V}_{\max }$ sulfate and $\mathrm{V}_{\max }{ }^{\text {APS }}$ as well as $\mathrm{V}_{\max }$ ATP and $\mathrm{V}_{\max }$ Pyrophosphate in both intestinal bacterial strains.

Michaelis constants $\left(K_{\mathrm{m}}\right)$ of ATP sulfurylase reaction was identified for $\mathrm{SO}_{4}^{2-}$, ATP, APS, and $\mathrm{PP}_{i}$ in the cell-free extracts of D. piger Vib-7 and Desulfomicrobium sp. Rod-9 strains. The values of $K_{\mathrm{m}}$ were similar for sulfate $(2.93 \pm 0.26,3.13 \pm 0.27 \mathrm{mM})$ and APS $(2.69 \pm 0.23,2.95 \pm 0.31 \mathrm{mM})$ in extracts of both strains, respectively. However, $K_{\mathrm{m}}$ for ATP $(1.98 \pm 0.21,1.07 \pm 0.12 \mathrm{mM})$ and $\mathrm{PP}_{\mathrm{i}}(19.41 \pm 1.85$, $11.07 \pm 1.11 \mathrm{mM}$ ) were significantly different from each other.

The obtained parameters of ATP sulfurylase reaction in the cell-free extracts of $D$. piger Vib-7 are consistent with previously described data by Gavel O. Yu. et al. for ATP sulfurylase activity in extracts of Desulfovibrio desulfuricans ATCC 27774 and Desulfovibrio gigas. Adenosine triphosphate sulfurylase catalyzes the formation of adenosine 5'-phosphosulfate from adenosine triphosphate and sulfate. The enzyme plays a crucial role in sulfate activation, the key step for sulfate utilization. ATP sulfurylase from $D$. desulfuricans and D. gigas was homotrimer and identified, for the first time, as metalloproteins containing cobalt and zinc. Furthermore, it was revealed that either cobalt or zinc binds endogenously to presumably equivalent metal binding sites and is tetrahedrally coordinated to one nitrogen and three sulfur atoms [6]. Perhaps, the described ATP sulfurylase from $D$. piger Vib-7 and Desulfomicrobium sp. Rod-9 can contain similar ions because activity of this enzyme in cell-free extracts of studied intestinal bacteria is very similar with activity previously described by Gavel O. Yu. et al. [6].

ATP sulfurylase (MgATP:sulfate adenylyltransferase, EC 2.7.7.4) catalyzes the first reaction in the activation of inorganic sulfate [18]:
APS is the substrate of the second "sulfate activating” enzyme (APS kinase; MgATP:APS 3'-phosphotransferase, EC 2.7.1.25) which forms PAPS [6]:

$$
\mathrm{ATP}+\mathrm{APS} \stackrel{\text { APS kinase, } \mathrm{Mg}^{2+}}{\rightleftharpoons} \text { ADP + PAPS }
$$

The action of inorganic pyrophosphatase helps drive the overall synthesis of PAPS $[10,16]$ :

$$
\mathrm{PP}_{\mathrm{i}}+\mathrm{H}_{2} \mathrm{O} \stackrel{\mathrm{PP}_{\mathrm{i}} \text { tase, } \mathrm{Mg}^{2+}}{\rightleftharpoons} 2 \mathrm{P}_{\mathrm{i}}
$$

PAPS serves as the sulfuryl donor for the biosynthesis of sulfate esters. In bacteria, PAPS also serves as the substrate for a reductive sulfate assimilation pathway leading to cysteine [2].

Kramer M. and Cypionka H. have demonstrated the ATP sulfurylase activity in Desulfovibrio sulfodismutans and $D$. desulfuricans CSN strains grown with thiosulfate, sulfite and $\mathrm{H}_{2}+$ sulfate. Enzyme activity of ATP sulfurylase required for sulfate reduction was detected in sufficient activities to account for the growth rates observed. It is proposed that during thiosulfate and sulfite disproportionation sulfate is formed via APS reductase and ATP sulfurylase [10].

Dissimilatory ATP sulfurylase from the hyperthermophilic sulfate reducer Archaeoglobus fulgidus belonging to the group of homo-oligomeric ATP sulfurylases was described by Sperling D. et al. [20]. The kinetic characteristics of $\mathrm{Mg}^{2+}$-dependent ATP hydrolysis (basal $\mathrm{Mg}^{2+}$-ATPase) in the cell membrane of bacteria Bacillus sp. was also demonstred by Danylovych G. V. et al. [5].

Based on the obtained studies results and according to the kinetic parameters of ATP sulfurylase reaction for both bacterial strains, we have concluded that the activity of ATP sulfurylase, $V_{0}$ and $V_{\max }$ were significantly higher in the $D$. piger Vib-7 cells than in Desulfomicrobium sp. Rod-9. However, Michaelis
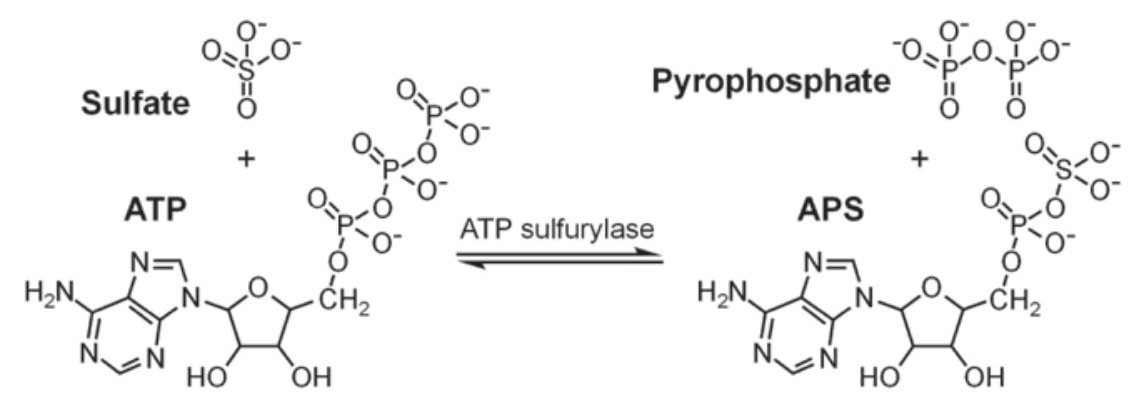
constants $K_{\mathrm{m}}$ Sulfate, $K_{\mathrm{m}}{ }^{\text {ATP }}, K_{\mathrm{m}}{ }^{\text {APS }}$, and $K_{\mathrm{m}}$ Pyrophosphate of the ATP sulfurylase reaction were similar for sulfate and ATP as well as significantly different for $\operatorname{ATP}(1.98 \pm 0.21,1.07 \pm 0.12 \mathrm{mM})$ and $\mathrm{PP}_{\mathrm{i}}(19.41$ $\pm 1.85,11.07 \pm 1.11 \mathrm{mM}$ ), for both $D$. piger Vib-7 and Desulfomicrobium sp. Rod-9, respectively. The maximum ATP sulfurylase activity for both strains was determined at $35{ }^{\circ} \mathrm{C}$ and at $\mathrm{pH} 8.0-8.5$. These data correspond to conditions which are present in the human large intestine from which the bacterial strains were isolated. Perhaps, such conditions provide their intensive development in the gut. The kinetic parameters of enzyme reaction depend on the substrate concentration. According to these data, the increase of sulfate concentration in the gut can lead to its active assimilation and, accordingly, to the accumulation of hydrogen sulfide in the lumen of large intestine. D. piger Vib-7 strain can be more dangerous and have some pathogenic significance in development of inflammatory bowel diseases, consuming sulfate and producing hydrogen sulfide at a higher velocity. The extensive studies of physiological and biochemical properties of the intestinal sulfate-reducing bacteria, the process of the dissimilatory sulfate reduction, in particular participation of ATP sulfurylase in this process, the activity and kinetic properties of this enzyme in the $D$. piger Vib-7 and Desulfomicrobium sp. Rod-9 bacterial strains, production of hydrogen sulfide by them can be perspective for revealing the etiological role of these bacteria in the development of various bowel diseases. The data on the concentration of hydrogen sulfide produced by the isolates is supposed to help in establishing and assessing the toxic effect of these compounds on the epithelial cells of the human and animal intestine. These studies might help in predicting the development of diseases of the gastrointestinal tract, by providing further details on the etiology of bowel diseases which are very important for clinical diagnostics of such diseases.

\section{КІНЕТИЧНІ ВЛАСТИВОСТІ \\ АДЕНОЗИНТРИФОСФАТ \\ СУЛЬФУРИЛАЗИ КИШКОВИХ \\ СУЛЬФАТВІДНОВЛЮВАЛЬНИХ БАКТЕРІЙ}

\author{
I. В. Кушкевич ${ }^{1,2}$, Г. Л. Антоняк ${ }^{3}$, \\ M. Бартош
}

${ }^{1}$ Інститут біології тварин НААН України, Львів;

${ }^{2}$ Університет ветеринарних та фармацевтичних наук Брно, Чеська Республіка;

$3^{3}$ Львівський національний університет імені Івана Франка, Україна;

e-mail: ivan.kushkevych@gmail.com

Досліджено питому активність та кінетичні властивості АТР-сульфурилази в безклітинних екстрактах кишкових бактеріальних штамів Desulfovibrio piger Vib-7 i Desulfomicrobium sp. Rod-9. У роботі використано мікробіологічні, біохімічні, біофізичні та статистичні методи досліджень. Визначено оптимальну температуру $\left(35^{\circ} \mathrm{C}\right)$ i $\mathrm{pH} 8,0-8,5$ для ензиматичної реакції. Проведено кінетичний аналіз властивостей АТР-сульфурилази. Визначено початкову (миттєву) швидкість реакції $\left(V_{0}\right)$, максимальну кількість продукту реакції $\left(\mathrm{P}_{\max }\right)$, час реакції (період напіврозпаду - насиченість, $\tau$ ) і максимальну швидкість АТР-сульфурилазної реакції $\left(V_{\max }\right)$. Обчислено константи Міхаеліса $\left(K_{\mathrm{m}}^{\text {Сульфату, }}\right.$ $\left.K_{\mathrm{m}}^{\mathrm{ATP}}, K_{\mathrm{m}}^{\text {AПC }} \mathrm{i} K_{\mathrm{m}}^{\text {Пірофосфату }}\right)$ для ензиматичної реакції обох кишкових бактеріальних штамів D. piger Vib-7 i Desulfomicrobium sp. Rod-9.

К л ючов і слова: кінетичний аналіз, сульфатвідновлювальні бактерії, Desulfovibrio piger, Desulfomicrobium sp., АТР-сульфурилаза, мікробіоценоз кишечника, запальні кишкові захворювання, виразкові коліти. 
КИНЕТИЧЕСКИЕ СВОЙСТВА

АДЕНОЗИНТРИФОСФАТ

СУЛЬФУРИЛАЗЫ КИШЕЧНЫХ

СУЛЬФАТВОССТАНАВЛИВАЮЩИХ

БАКТЕРИЙ

\section{И. В. Кушкевич1,2, Г. Л. Антоняк ${ }^{3}$, M. Бартош ${ }^{2}$}

${ }^{1}$ Институт биологии животных НААН Украины, Львов;

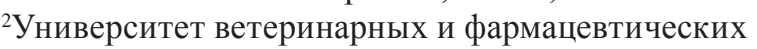
наук Брно, Чешская Республика;

$3^{3}$ Јвовский национальный университет имени Ивана Франко, Украина; e-mail: ivan.kushkevych@gmail.com

Исследована удельная активность и кинетические свойства АТР-сульфурилазы в бесклеточных экстрактах кишечных бактериальных штаммов Desulfovibrio piger Vib-7 и Desulfomicrobium sp. Rod-9. В работе использованы микробиологические, биохимические, биофизические и статистические методы исследований. Определена оптимальная температура $\left(35^{\circ} \mathrm{C}\right)$ и $\mathrm{pH} 8,0-8,5$ для энзиматической реакции. Проведен кинетический анализ свойств АТР-сульфурилазы. Установлена начальная (мгновенная) скорость реакции $\left(V_{0}\right)$, максимальное количество продукта реакции $\left(\mathrm{P}_{\max }\right)$, время реакции (период полураспада - насыщенность, $\tau)$ и максимальная скорость АТР-сульфурилазной реакции $\left(V_{\max }\right)$. Рассчитаны константы Михаэлиса ( $K_{\mathrm{m}}^{\text {сульфата }}$, $K_{\mathrm{m}}{ }^{\mathrm{ATP}}, K_{\mathrm{m}}{ }^{\text {AПC }}$ и $K_{\mathrm{m}}^{\text {Пирофосфата) }}$ для энзиматической реакции обоих кишечных бактериальных штаммов D. piger Vib-7 и Desulfomicrobium sp. Rod-9.

К лючевы е слова: кинетический анализ, сульфатвосстанавливающие бактерии, Desulfovibrio piger, Desulfomicrobium sp., ATPсульфурилаза, микробиоценоз кишечника, воспалительные кишечные заболевания, язвенные колиты.

\section{References}

1. Bailey N. T. J. Statistical Methods in Biology. Cambridge University Press, 1995. 252 p.

2. Barton L. L., Hamilton W. A. Sulphate-reducing Bacteria. Environmental and Engineered. Cambridge University Press, 2007. 553 p.

3. Cummings J. H., Macfarlane G. T., Macfarlane S. Intestinal bacteria and ulcerative colitis. Curr. Issues Intest. Microbiol. 2003;4:9-20.
4. Dahl C., Truper H. G. Enzymes of dissimilatory sulfide oxidation in phototrophic bacteria. Methods Enzymol. 1994;243:400-421.

5. Danylovych G. V., Gruzina T. G., Ulberg Z. R., Kosterin S. O. Effect of ionic and colloid gold on ATP-hydrolase fermentative systems of Bacillus sp. B4253 and Bacillus sp. B4851. Ukr. Biokhim. Zhurn. 2007;79(4)46-53. (In Ukrainian).

6. Gavel O. Y., Bursakov S. A., Calvete J. J. George G. N., Moura J. J., Moura I. ATP sulfurylases from sulfate-reducing bacteria of the genus Desulfovibrio. A novel metalloprotein containing cobalt and zinc. Biochemistry. 1998;37:16225-16232.

7. Gibson G. R., Cummings J. H., Macfarlane G. T. Growth and activities of sulphate-reducing bacteria in gut contents of health subjects and patients with ulcerative colitis. FEMS Microbiol. Ecol. 1991;86:103-112.

8. Keleti T. Basic Enzyme Kinetics. Akademiai Kiado, 1988. 422 p.

9. Kosterin S. A., Burchynskaya N. F. The method for determining the characteristics kinetics of the $\mathrm{Ca}^{2+}$-transport systems subcells structures of smooth muscles. Ukr. Biokhim. Zurn. 1987;59(2):66-69. (In Russian).

10. Kramer M., Cypionka H. Sulfate formation via ATP sulfurylase in thiosulfate- and sulfitedisproportionating bacteria. Arch. Microbiol. 1989;151:232-237.

11. Kushkevych I. V. Sulfate-reducing bacteria of the human intestine. I. Dissimilatory sulfate reduction. Studia Biologica. 2012;6(1):149-180. (In Ukrainian).

12. Kushkevych I. V. Sulfate-reducing bacteria of the human intestine. II. The role in the diseases development. Studia Biologica. 2012;6(2):221250. (In Ukrainian).

13. Kushkevych I. V. Identification of sulfatereducing bacteria strains of human large intestine. Studia Biologica. 2013;7(3):115-124.

14. Kushkevych I. V., Bartos M., Bartosova L. Sequence analysis of the 16S rRNA gene of sulfate-reducing bacteria isolated from human intestine. Int. J. Curr. Microbiol. Appl. Sci. 2014;3(2):239-248.

15. Lowry O. H., Rosebrough N. J, Farr A. L., Randall R. J. Protein determination with the Folin phenol reagent. J. Biol. Chem. 1951;193:265-275.

16. Peck H. D., Van Beeumen J., LeGall J. Biochemistry of Dissimilatory Sulphate 
Reduction and Discussion. Phil. Trans. R. Soc. Lond. B. 1982;298:443-466.

17. Phartiyal P., Kim W. S., Cahoon R. E., Jez J. M., Krishnan, H. B. Soybean ATP sulfurylase, a homodimeric enzyme involved in sulfur assimilation, is abundantly expressed in roots and induced by cold treatment. Arch. Biochem. Biophys. 2006;450:20-29.

18. Ravilious G. E., Herrmann J., Lee S. G., Westfall C. S., Jez J. M. Kinetic mechanism of a dimeric ATP sulfurylase from plants. Biosci. Rep. 2013;33(4):585-591.
19. Segal I. H. Enzyme kinetics: behavior and analysis of rapid equilibrium and steady-state enzyme systems. John Wiley \& Sons, New York. 1975.

20. Sperling D., Kappler U., Wynen A., Dahl C., Truper H. G. Dissimilatory ATP sulfurylase from the hyperthermophilic sulfate reducer Archaeoglobus fulgidus belongs to the group of homo-oligomeric ATP sulfurylases. FEMS Microbiol. Letters. 1998;162(2):257-264.

Received 20.05.2014 